medRxiv preprint doi: https://doi.org/10.1101/2020.11.02.20224642; this version posted November 4,2020 . The copyright holder for this preprint (which was not certified by peer review) is the author/funder, who has granted medRxiv a license to display the preprint in All rights reserved. No reuse allowed without permission.

\title{
Vascular Thrombosis in COVID-19: A Potential Association with Antiphospholipid
}

\section{Antibodies}

A Rapid Systematic Review

Aneesh S Kallapur, MBBS1; Eric Y Yen, MD, MS¹; Ram Raj Singh, MD1,2,3,4

${ }^{1}$ Department of Medicine, University of California at Los Angeles (UCLA) David Geffen

School of Medicine, Los Angeles, CA, ${ }^{2}$ Jonsson Comprehensive Cancer Center, UCLA, Los Angeles, CA, ${ }^{3}$ Molecular Toxicology Interdepartmental Program, UCLA, Los Angeles, CA, ${ }^{4}$ Department of Pathology and Laboratory Medicine, UCLA, Los Angeles, CA.

Corresponding author: Ram Raj Singh, MD, Autoimmunity and Tolerance Laboratory, Division of Rheumatology, UCLA, 1000 Veteran Avenue, Room 32-59, Los Angeles, CA 90095-1670 (rrsingh@mednet.ucla.edu).

Word count: 3,047 (Introduction to Conclusion) 


\section{ABSTRACT}

Background: Vascular thrombosis is common in patients with coronavirus disease 2019 (COVID-19). Etiologies underlying this complication are unclear.

Purpose: To determine the prevalence of antiphospholipid (aPL), including lupus anticoagulant, anti-cardiolipin and anti- $\beta 2$-glycoprotein- 1 antibodies, and its possible association with thrombotic manifestations of COVID-19.

Data Sources: We searched MEDLINE indexed journals on September 24, 2020 using the tool LitCovid and the pre-print server medRxIV.

Study Selection: Original investigations (cross-sectional studies, cohort studies, case series, and research letters) on COVID-19 and thrombosis were included.

Data Extraction: Data were independently extracted, and compiled into spreadsheets based on the PRISMA principles.

Data Synthesis: Hospitalized patients with COVID-19 showed a higher prevalence of lupus anticoagulant compared to non-COVID-19 patients. Temporally, lupus anticoagulant was generally positive early in the course of illness, whereas anticardiolipin and anti- $\beta 2$-glycoprotein-1 antibodies appeared to emerge later in the disease. Some patients who were aPL-negative at an early time-point after disease onset became aPL-positive at a later time-point. Lupus anticoagulant was independently associated with thrombosis in 60 COVID-19 patients in New York had who had 32 thrombotic events (8 arterial and 24 venous). In 88 patients in Wuhan, who had more than 20 each of arterial and venous thrombotic events, medium/high positivity for multiple aPL was significantly associated with arterial thrombosis. However, the association of aPL with thrombosis was not evident in reports that had an overall lower number of or predominantly venous thrombotic events. Analysis of pooled patients revealed that aPL were significantly more frequent in COVID-19 patients with stroke 
than stroke patients in the general population. Furthermore, injection of IgG aPL fractions from COVID-19 patients into mice accelerated venous thrombosis.

Limitation: Limited data and paucity of prospective studies.

Conclusion: The aPL are prevalent in patients with COVID-19 and their presence is associated with thrombosis. Importantly, these antibodies may be a key mechanism of thrombosis in COVID-19. Follow-up studies are required to understand the relationship between aPL and the spectrum of vascular thrombosis during and after infection with SARS-CoV-2.

Primary Funding Source: None. 


\section{INTRODUCTION}

The coronavirus disease 2019 (COVID-19) pandemic, caused by the severe acute respiratory syndrome coronavirus-2 (SARS-CoV-2) has resulted in tremendous morbidity and mortality. Many patients with COVID-19 exhibit hypercoagulable states, with manifestations ranging from disseminated intravascular coagulation to venous thromboembolism and cerebrovascular disease (1). Among patients with acute respiratory distress syndrome, more thrombotic complications were diagnosed in COVID-19 patients than in matched patients without COVID-19 (odds ratio 2.6 [1.16.1]) (2). An autopsy study detected venous thromboembolism in more than half of deceased COVID-19 patients in whom it was not suspected earlier (3).

As these thrombotic manifestations began being reported at high rates, attempts are being made to uncover the underlying etiologies. A report from Wuhan, China, in April 2020 described three COVID-19 patients who developed thrombosis including multiple-vessel brain infarction and acro- ischemia (4). All three patients had anticardiolipin (aCL) and anti- $\beta 2$ glycoprotein-1 (aß2GP1) antibodies, collectively called antiphospholipid (aPL) antibodies.

The presence of aPL antibodies and a functional assay called lupus anticoagulant (LA) are the hallmarks of antiphospholipid syndrome (APS) that manifests with venous and arterial thrombosis (5). Some patients with APS have no other associated condition (primary APS), while others can be associated with infections and autoimmune disorders. Various infections, notably Hepatitis C virus (HCV) and HIV, have been shown to induce aPL antibodies, however, the significant thrombotic risk with aPL was seen only in HCV infection $(6,7)$. It is unclear whether SARS-CoV-2 elicits the production of aPL that associate with increased thrombotic risk. 
In this systematic review, we identify patients with COVID-19 and thrombosis who were tested for aPL, and determine the prevalence of aPL in this population compared to the general population with reference to specific thrombotic manifestations. We further seek if any causal relationship exists between the presence of aPL in these patients and thrombosis.

\section{Methods}

Data Sources and Searches: We searched MEDLINE indexed journals using the tool LitCovid (8) on September 24, 2020. Due to the rapidly changing landscape of research in COVID-19, we also searched the pre-print server medRxIV, with the acknowledgment that those articles are not peer-reviewed.

Study Selection: We included all original investigations (cross-sectional studies, cohort studies, case series, case reports and research letters) relevant to adult patients in the English language. We used the following search terms: "COVID-19”, “Coronavirus”, "ncov", "2019-ncov" and "Antiphospholipid antibodies”, "Antiphospholipid antibody syndrome”, "Lupus anticoagulant" and "Stroke”, "Venous thromboembolism”, “Deep vein thrombosis" (DVT), "Myocardial infarction" and "Acute limb ischemia". Articles that did not contain any laboratory data and those which did not carry out testing for aPL were excluded.

Data Extraction and Quality Assessment: Data were extracted by one reviewer (A.K.), and independently reviewed by other two authors. We assessed article for the quality of evidence (Appendix Table 1). 
Data Synthesis and Analysis: First, to assess the prevalence of aPL in COVID-19, we compiled studies that reported aPL assays in patients with COVID-19. Second, we compiled studies that reported aPL assays in COVID-19 patients in relation to thrombosis. Third, we compared the frequency of aPL in patients with stroke in the general population versus COVID-19 using Fisher's exact test.

Role of the Funding Source: Not applicable.

\section{Results}

We found 4,354 search results for these queries, of which 221 results were relevant (Appendix Figure 1). After excluding 59 articles that did not report any laboratory parameters and 104 articles that did not test for aPL antibodies, we were left with 58 articles reporting thrombotic events in COVID-19 patients who were tested for aPL antibodies, which we included in our systematic review.

\section{Antiphospholipid positivity in patients with COVID-19}

Studies from Europe and the United States have shown a very high prevalence of LA in patients with COVID-19, ranging from 19\% to $92 \%$ (Table 1, Figure 1). The prevalence of LA was significantly higher in COVID-19 patients than in non-COVID-19 controls, for example, $44 \%$ vs. $22 \%$ in New York, and $\sim 19 \%$ vs. $2 \%$ in UK $(9,10)$. The prevalence of LA was also higher in Italian COVID-19 patients than in patients with other autoimmune rheumatic diseases (22\% vs. $15 \%$ ), but lower than in patients with primary APS (56\%) (11). Contrary to these reports, patients from China were reported to have a much lower prevalence of LA - 3\% of 66 and $5 \%$ of 19 patients in Wuhan and 0 of 13 in Beijing $(12,13)$. However, Chinese patients had a much higher prevalence of a $\beta 2 \mathrm{GP} 1$ 
and aCL antibodies (47\%-53\%). These patients were tested at later time points ( $29-39$ days) after disease onset than in most European and American studies. Consistently, aCL/aß2GP1 positive French patients tended to have been tested longer after COVID-19 symptoms started than the negative patients (14). Furthermore, 10 Chinese patients who were aPL negative at an early time point after disease onset became aPL positive later (12), and a French patient with isolated IgM aCL seroconverted to IgG aCL and $\mathrm{a} \beta_{2} \mathrm{GP} 1$ antibodies (14).

IgA a $\beta 2$ GP1, IgA aCL, and IgG a $\beta 2 \mathrm{GP} 1$ antibodies were the most prevalent aPL in Chinese patients, with many of them positive for multiple isotypes $(12,13)$. IgG a $\beta 2 G P 1$ antibodies were also most frequent in a report from Italy(15). Reports from Michigan and Mexico also showed a high prevalence of the non-criteria antiphosphatidylserine/prothrombin antibodies $(16,17)$. IgA antibodies were not tested in many European and American studies.

As a whole, reports from around the world appear to suggest a high prevalence of LA at early time points after COVID-19 infection, whereas aPL antibodies emerge later in the disease course. This suggests that COVID-19 patients who have a longer disease duration are more likely to have aPL antibodies.

\section{Antiphospholipid positivity in relation to thrombosis in COVID-19 patients}

An early report described three COVID-19 patients with multi-vessel brain infarction, acro-ischemia, and IgA/IgG aCL and aß2GP1 antibodies (4). This was followed by a flurry of reports seeking a relation between aPL antibodies and thrombosis in COVID-19 (Table 2 and Appendix Table 2).

In 66 COVID-19 patients from Wuhan, 38\% developed arterial or venous thrombosis, and nearly half of all patients were positive for aPL antibodies (12). When 
stratified based on positivity for aPL antibodies, patients with medium/high positivity for multiple aPL antibodies showed a significantly higher incidence of cerebral infarction compared to patients with negative aPL antibodies ( 0 vs. 33.3\%, p 0.023). In another report from Wuhan, 9 of 10 patients who were aPL positive as compared to 0 of 9 aPL-negative patients developed thrombosis; all patients were already receiving anticoagulation(13). All four patients who developed cerebral infarction had multiple isotypes of aPL antibodies detectable.

Such a tight link between the presence of aPL antibodies and thrombosis in COVID-19 patients was not apparent in reports from Europe. Nonetheless, $24 \%$ of Italian patients with at least one aPL developed thrombosis versus $12 \%$ of patients who were aPL negative (p 0.09) (11). Thrombotic events in this report were almost exclusively venous, and $50 \%$ of all patients were positive for at least one aPL. In another report from Italy, 13\% of patients had a thrombotic event including 8 each of arterial and venous thrombosis and 6\%-16\% had various aPL, but there was no significant association between thrombosis and aPL (15). Venous events, namely DVT and pulmonary embolism (PE), were also frequent in French patients, and aPL antibody positivity tended to be more frequent in patients with thrombosis than in those without it, but the differences were not statistically significant $(14,18)$. No association with aPL was found in patients from Spain and Belgium who had predominantly venous thrombosis $(19,20)$. Likewise, a Michigan study found no significant association between aPL positivity and thrombosis in patients who received a stricter thromboprophylaxis and had a low frequency of thrombotic complications (6\%) (16). Overall, most reports from Europe did not support a significant relationship between aPL positivity and thrombosis in patients with COVID-19. Most of these studies had a 
relatively small number of thrombotic events and did not stratify them into arterial and venous events separately to ascertain specific relations with aPL antibodies.

In a New York cohort of 60 patients with COVID-19 who had 32 thrombotic events including 8 arterial and 24 venous, LA was found to be independently associated with thrombosis (10). All of the arterial thrombotic events and 11 venous thromboembolism occurred in LA-positive patients as compared to LA-negative patients who had only venous events. All 4 patients with COVID-19 and stroke in a UK report were also positive for LA (21). Overall, these reports suggest a potential link between aPL antibodies and thrombosis in COVID-19.

\section{Antiphospholipid antibodies and individual manifestations of APS in patients with COVID-19}

Next, to seek any potential links between aPL and individual APS manifestations in COVID-19, we compared the frequency of aPL in patients with specific manifestations in COVID-19 to the general population, the latter as reported in a systematic review of 120 full-text papers (22). The overall aPL frequency in this analysis was estimated to be $13.5 \%$ for stroke, $11 \%$ for myocardial infarction, $9.5 \%$ for DVT, and $6 \%$ for pregnancy morbidity in the general population.

Of 438 COVID-19 patients with ischemic stroke, 65 were tested for aPL antibodies, and $38(58.4 \%)$ were found to be positive (Table 3 ). Compared to the overall frequency of aPL in stroke patients in the general population, which was $13.5 \%$ (interquartile range 6.8-23.3) in all 31 studies and 7.5\% (5.3-13.8) in 7 prospective studies(22), COVID-19 patients with stroke had a significantly higher frequency of aPL ( $p<0.0001$, Figure 2). This profound difference in the prevalence of aPL antibodies in stroke patients with and without SARS-CoV-2 infection suggests a link between 
ischemic stroke and aPL antibodies in COVID-19, with a caveat that the two groups of patients are different in terms of comorbidities, age, state of health, and other demographic factors.

There were notable differences in the prevalence of aPL antibodies in COVID-9 patients with stroke from different continents: $94.4 \%$ in Chinese patients with ischemic stroke, 55\% in European patients, and 37\% in American patients (Table 3).

In addition to stroke, arterial thrombosis in SARS-CoV-2 infection has manifested with myocardial infarction, acute limb ischemia, and thrombosis of large arteries (23, 24). Thus far, there are only a few reports of aPL antibodies in patients with myocardial infarction and acute limb ischemia (Table 2, Appendix Table 2).

Venous thrombosis in patients infected with SARS-CoV-2 has predominantly manifested as DVT and PE and occasionally as cerebral venous thrombosis and portal vein thrombosis. Among 150 COVID-19 patients referred to intensive care units of a French tertiary hospital, 64 thrombotic complications occurred, including PE (16.7\%) (2). Notably, $87.7 \%$ of 57 patients suspected to have a coagulation disorder and tested had a positive LA. This frequency of aPL in venous thrombosis in COVID-19 patients appears much higher $(27 / 87=31 \%)$ than aPL frequency in venous thrombosis patients in the general population (9.5\%) (22). However, the testing and reporting of aPL are inadequate at this time for most of 648 patients with PE and 430 patients with DVT from around the world to make statistical comparisons.

Pregnancy loss is also a major manifestation of APS. Of 458 pregnancies in hospitalized patients with COVID-19 in the US, pregnancy loss occurred in $10(2.2 \%)$ including four that occurred within 20 weeks of gestation (25). There have also been case reports of $1^{\text {st }}$ and $2^{\text {nd }}$-trimester miscarriages in asymptomatic or minimally 
symptomatic women (26). We have not found studies of aPL in relation to pregnancy outcome.

Thrombocytopenia occurs in $22 \%-42 \%$ of patients with APS. It has been reported in $5 \%$ to $54 \%$ of patients with COVID-19, with the incidence varying according to disease severity (27). It has also been reported in many asymptomatic patients. However, its association with aPL has not been explored in COVID-19.

Livedo reticularis-like vascular lesions, the most common skin manifestation of APS, have been reported in 2\%-5\% of patients with COVID-19 (28). Its association with aPL antibodies has not been explored.

Akin to reports in patients with APS, higher levels of aPL in COVID-19 patients were associated with neutrophil hyperactivity including the release of neutrophil extracellular traps (NET), and IgG fractions isolated from patients with COVID-19 promoted NET release from control neutrophils (16).

\section{Pathogenic significance of antiphospholipid antibodies}

A report from Belgium found single LA positivity during the acute phase of COVID-19 infection, but not when tested one month later. This led them to suggest that COVID-19, like other viral infections, causes a transient production of aPL antibodies in critically ill patients, which may be of no clinical significance $(6,20)$. However, other studies detected aPL antibodies more than a month after the onset of symptoms, and many patients who were aPL negative at an early time point became positive later $(12,15)$. In Chinese studies, all symptomatic thrombotic events occurred in aPL positive patients (4, $12,13)$. Higher levels of aPL were also associated with more severe respiratory disease and lower glomerular filtration rate in COVID-19 patients(16). Importantly, similar to studies in APS (29), injection of IgG fractions from COVID-19 patients into mice 
accelerated venous thrombosis (16). Collectively, these studies suggest that aPL are potentially thrombogenic in patients with COVID-19.

\section{Discussion}

Viral infections are known to elicit the production of aPL antibodies, but the antibodies are generally transient and rarely cause thrombosis except for HIV and HCV that mainly induce IgG aCL antibodies (6). Thromboembolic events in patients with HCV were predominantly in patients who had aCL antibodies and were negative for LA and aß2GP1(7). This is different from the aPL profile reported in COVID-19. The presence of LA was independently associated with thrombosis in patients with COVID-19 in some, but not in all studies. In COVID-19 patients in Wuhan, positivity for multiple aPL, including aCL and aß2GP1 antibodies, of multiple isotypes at medium-to-high titers were significantly associated with arterial thrombosis $(12,13)$, which is consistent with the literature on APS that double and triple aPL positivity is associated with the increased risk for thrombosis (30).

IgA aCL, IgA aß2GP1, and IgG aß2GP1 antibodies were the most common aPL in COVID-19 patients in Wuhan (12). There was a striking association between the presence of these antibodies and cerebral infarction. The latter has important implications, as IgA a 32 GPI has been suggested as a risk factor for acute myocardial infarction and acute cerebral ischemia (31). Other studies have also linked IgA aPL antibodies to a higher risk of thrombosis (32). It is postulated that the infection of the respiratory and gastrointestinal mucosa by SARS-CoV-2 may elicit the IgA antibody production, which could go on to cause thrombosis (12). These observations warrant that IgA aPL, although not part of the diagnostic criteria for APS, be uniformly tested in addition to IgG/M aPL in patients with acute arterial ischemic events and COVID-19. 
The significantly higher aPL antibody positive rate in China compared to the USA and Europe could be due to various reasons. Chinese studies tested IgA antibodies, while patients in Europe and the US were mostly not tested for them. Chinese patients with stroke could also have had SARS-CoV-2 infection for a longer duration. It is also possible that APS is an important mechanism of thrombosis in severely ill SARS-CoV-2 patients, which had not been (at the time of this study) adequately tested in the US and Europe.

Our analysis has several limitations. First, the Sapporo classification criteria for APS requires the aPL to be measured twice over a period of 12 weeks to establish that the levels are not transient (33). In this regard, most studies have tested aPL in hospitalized patients with SARS-CoV-2 infection within days of the onset of symptoms. Therefore, follow up studies are required to truly understand whether the patient developed APS or simply had a transient elevation of aPL.

Second, the guidelines from the International Society on Thrombosis and Hemostasis state that anticoagulation must be discontinued for 12 hours before the testing for LA or the testing must be done before anticoagulation is started (34). Since critically ill patients are often anticoagulated, it is important to interpret a positive LA result with caution in this setting. Elevated levels of the acute phase reactant C-reactive protein, as commonly seen in patients hospitalized with COVID-19, have also been shown to interfere with reagents commonly used to test LA (35). Antibody assays for aCL and aß2GP1 antibodies also suffer from a lack of standardization and the presence of inter-laboratory variation, which can influence the interpretation of tests with borderline results (36).

Third, many patients with COVID-19 in most reports analyzed had comorbidities including diabetes and hypertension, which could contribute to a pro-thrombotic 
milieu. Other complications, including heparin-induced thrombocytopenia, disseminated intravascular coagulation, and thrombotic microangiopathy, could also be causes of thrombosis in these critically ill patients. We also acknowledge the risk of bias including, but not limited to, possible poor/inadequate reporting in individual articles, potential lack of external validity, potential selective outcome reporting in individual articles, evidence selection bias due to non-publication, new information published after our cut-off date, and articles in non-English languages,

Finally, it has been suggested that catastrophic APS could be a possible explanation of the cytokine storm in some patients with severe COVID-19. Catastrophic APS is a fulminant form of APS that presents with widespread small vessel thrombosis. However, unlike catastrophic APS that manifests predominantly with intra-abdominal thrombosis, patients who died from COVID-19 had a predominance of pulmonary microvascular thrombosis (37).

Studies in APS suggest a direct pathogenic role of aPL antibodies, as the experimental transfer of polyclonal IgG antibodies against domain I of $\beta 2$ glycoprotein from a patient with APS into mice induced thrombosis in blood vessels (29). Consistently, injection of IgG fractions from COVID-19 patients who have aPL antibodies into mice accelerated venous thrombosis (16). The current working model of APS pathogenesis invokes a "two-hit hypothesis", whereby the presence of aPL antibodies (the first-hit) would predispose to thrombosis upon exposure to a second hit such as infection or local tissue damage (38). Antiphospholipid antibodies are postulated to cause thrombosis via activation of endothelial cells, neutrophils, monocytes, platelets, and the complement cascade (39), which are similarly activated in COVID-19 infection likely due to the cytokine storm that occurs in some patients with COVID-19 (40). Taken together, it would be reasonable to postulate that the presence of aPL antibodies along 
with activation of endothelial and other immune cells could underlie the serious vascular complications in patients with COVID-19.

There are wide-ranging implications if it is proven that aPL antibodies are thrombogenic in COVID-19. For one, testing of aPL could be recommended for critically ill patients if it is proven that aPL positivity is a harbinger of future thrombotic events. In addition, the patients who have detectable aPL antibodies for 12 weeks or more can be diagnosed with APS and thus become candidates for long-term anticoagulation, thereby decreasing their long-term risk of vascular events.

\section{CONCLUSIONS}

In conclusion, a substantial proportion of patients with COVID-19 exhibit aPL positivity. Follow-up testing is needed to identify whether these antibodies persist and pose a thrombosis risk in the future. Experimental transfer studies showing venous thrombosis in mice injected with human IgG from COVID-19 patients with aPL suggest a potential pathogenicity of these antibodies (16), however, more studies are needed to establish a causal relation between aPL positivity and thrombosis in COVID-19. 


\section{References}

1. Al-Ani F, Chehade S, Lazo-Langner A. Thrombosis risk associated with COVID-19 infection. A scoping review. Thromb Res. 2020;192:152-60.

2. Helms J, Tacquard C, Severac F, Leonard-Lorant I, Ohana M, Delabranche X, et al. High risk of thrombosis in patients with severe SARS-CoV-2 infection: a multicenter prospective cohort study. Intensive Care Med. 2020;46(6):1089-98.

3. Wichmann D, Sperhake JP, Lütgehetmann M, Steurer S, Edler C, Heinemann A, et al. Autopsy Findings and Venous Thromboembolism in Patients With COVID-19: A Prospective Cohort Study. Ann Intern Med. 2020;173(4):268-77.

4. Zhang Y, Xiao M, Zhang S, Xia P, Cao W, Jiang W, et al. Coagulopathy and Antiphospholipid Antibodies in Patients with Covid-19. N Engl J Med. 2020;382(17):e38.

5. Cervera R. Antiphospholipid syndrome. Thromb Res. 2017;151 Suppl 1:S43-s7.

6. Asherson RA, Cervera R. Antiphospholipid antibodies and infections. Ann Rheum Dis. 2003;62(5):388-93.

7. Abdel-Wahab N, Talathi S, Lopez-Olivo MA, Suarez-Almazor ME. Risk of developing antiphospholipid antibodies following viral infection: a systematic review and meta-analysis. Lupus. 2018;27(4):572-83.

8. Chen $Q$, Allot A, Lu Z. Keep up with the latest coronavirus research. Nature. 2020;579(7798):193.

9. Bowles L, Platton S, Yartey N, Dave M, Lee K, Hart DP, et al. Lupus Anticoagulant and Abnormal Coagulation Tests in Patients with Covid-19. N Engl J Med. 2020;383(3):288-90.

10. Reyes Gil M, Barouqa M, Szymanski J, Gonzalez-Lugo JD, Rahman S, Billett HH. Assessment of Lupus Anticoagulant Positivity in Patients With Coronavirus Disease 2019 (COVID-19). JAMA Netw Open. 2020;3(8):e2017539.

11. Gatto M, Perricone C, Tonello M, Bistoni O, Cattelan AM, Bursi R, et al. Frequency and clinical correlates of antiphospholipid antibodies arising in patients with SARS-CoV-2 infection: findings from a multicentre study on 122 cases. Clin Exp Rheumatol. 2020;38(4):754-9.

12. Xiao M, Zhang Y, Zhang S, Qin X, Xia P, Cao W, et al. Brief Report: Anti-phospholipid antibodies in critically ill patients with Coronavirus Disease 2019 (COVID-19). Arthritis Rheumatol. 2020.

13. Zhang $\mathrm{Y}$, Cao $\mathrm{W}$, Jiang $\mathrm{W}$, Xiao $\mathrm{M}$, Li Y, Tang N, et al. Profile of natural anticoagulant, coagulant factor and anti-phospholipid antibody in critically ill COVID-19 patients. J Thromb Thrombolysis. 2020:1-7.

14. Siguret V, Voicu S, Neuwirth M, Delrue M, Gayat E, Stépanian A, et al. Are antiphospholipid antibodies associated with thrombotic complications in critically ill COVID-19 patients? Thromb Res. 2020;195:74-6.

15. Borghi MO, Beltagy A, Garrafa E, Curreli D, Cecchini G, Bodio C, et al. Prevalence, specificity, and clinical association of anti-phospholipid antibodies in COVID-19 patients: are the antibodies really guilty? medRxiv. 2020.

16. Zuo Y, Estes SK, Gandhi AA, Yalavarthi S, Ali RA, Shi H, et al. Prothrombotic antiphospholipid antibodies in COVID-19. medRxiv. 2020.

17. Amezcua-Guerra LM, Rojas-Velasco G, Brianza-Padilla M, Vázquez-Rangel A, MárquezVelasco R, Baranda-Tovar F, et al. Presence of antiphospholipid antibodies in COVID-19: case series study. Ann Rheum Dis. 2020.

18. Pineton de Chambrun M, Frere C, Miyara M, Amoura Z, Martin-Toutain I, Mathian A, et al. High frequency of antiphospholipid antibodies in critically ill COVID-19 patients: a link with hypercoagulability? J Intern Med. 2020.

19. Galeano-Valle F, Oblitas CM, Ferreiro-Mazón MM, Alonso-Muñoz J, Del Toro-Cervera J, di Natale $\mathrm{M}$, et al. Antiphospholipid antibodies are not elevated in patients with severe COVID19 pneumonia and venous thromboembolism. Thromb Res. 2020;192:113-5. 
20. Devreese KMJ, Linskens EA, Benoit D, Peperstraete $\mathrm{H}$. Antiphospholipid antibodies in patients with COVID-19: A relevant observation? J Thromb Haemost. 2020.

21. Beyrouti R, Adams ME, Benjamin L, Cohen H, Farmer SF, Goh YY, et al. Characteristics of ischaemic stroke associated with COVID-19. J Neurol Neurosurg Psychiatry. 2020;91(8):88991.

22. Andreoli L, Chighizola CB, Banzato A, Pons-Estel GJ, Ramire de Jesus G, Erkan D. Estimated frequency of antiphospholipid antibodies in patients with pregnancy morbidity, stroke, myocardial infarction, and deep vein thrombosis: a critical review of the literature. Arthritis Care Res (Hoboken). 2013;65(11):1869-73.

23. Etkin Y, Conway AM, Silpe J, Qato K, Carroccio A, Manvar-Singh P, et al. Acute Arterial Thromboembolism in Patients with COVID-19 in the New York City Area. Ann Vasc Surg. 2020.

24. Kashi $M$, Jacquin $A$, Dakhil B, Zaimi R, Mahé E, Tella $E$, et al. Severe arterial thrombosis associated with Covid-19 infection. Thromb Res. 2020;192:75-7.

25. Delahoy MJ, Whitaker M, O'Halloran A, Chai SJ, Kirley PD, Alden N, et al. Characteristics and Maternal and Birth Outcomes of Hospitalized Pregnant Women with Laboratory-Confirmed COVID-19 - COVID-NET, 13 States, March 1-August 22, 2020. MMWR Morb Mortal Wkly Rep. 2020;69(38):1347-54.

26. Wong TC, Lee ZY, Sia TLL, Chang AKW, Chua HH. Miscarriage Risk in COVID-19 Infection. SN Compr Clin Med. 2020:1-4.

27. Cheung CKM, Law MF, Lui GCY, Wong SH, Wong RSM. Coronavirus Disease 2019 (COVID-19): A Haematologist's Perspective. Acta Haematol. 2020:1-14.

28. Freeman EE, McMahon DE, Lipoff JB, Rosenbach M, Kovarik C, Desai SR, et al. The spectrum of COVID-19-associated dermatologic manifestations: An international registry of 716 patients from 31 countries. J Am Acad Dermatol. 2020;83(4):1118-29.

29. Pericleous C, Ruiz-Limón P, Romay-Penabad Z, Marín AC, Garza-Garcia A, Murfitt L, et al. Proof-of-concept study demonstrating the pathogenicity of affinity-purified IgG antibodies directed to domain I of $\beta 2$-glycoprotein I in a mouse model of anti-phospholipid antibodyinduced thrombosis. Rheumatology (Oxford). 2015;54(4):722-7.

30. Lim W. Prevention of thrombosis in antiphospholipid syndrome. Hematology Am Soc Hematol Educ Program. 2016;2016(1):707-13.

31. Andreoli L, Fredi M, Nalli C, Piantoni S, Reggia R, Dall'Ara F, et al. Clinical significance of IgA anti-cardiolipin and IgA anti-beta2glycoprotein I antibodies. Curr Rheumatol Rep. 2013;15(7):343.

32. Murthy V, Willis R, Romay-Penabad Z, Ruiz-Limón P, Martínez-Martínez LA, Jatwani S, et al. Value of isolated IgA anti- $\beta 2$-glycoprotein I positivity in the diagnosis of the antiphospholipid syndrome. Arthritis Rheum. 2013;65(12):3186-93.

33. Miyakis S, Lockshin MD, Atsumi T, Branch DW, Brey RL, Cervera R, et al. International consensus statement on an update of the classification criteria for definite antiphospholipid syndrome (APS). J Thromb Haemost. 2006;4(2):295-306.

34. Pengo V, Tripodi A, Reber G, Rand JH, Ortel TL, Galli M, et al. Update of the guidelines for lupus anticoagulant detection. Subcommittee on Lupus Anticoagulant/Antiphospholipid Antibody of the Scientific and Standardisation Committee of the International Society on Thrombosis and Haemostasis. J Thromb Haemost. 2009;7(10):1737-40.

35. Schouwers SM, Delanghe JR, Devreese KM. Lupus Anticoagulant (LAC) testing in patients with inflammatory status: does C-reactive protein interfere with LAC test results? Thromb Res. 2010;125(1):102-4.

36. Devreese KM. Antiphospholipid antibody testing and standardization. Int J Lab Hematol. 2014;36(3):352-63.

37. Elsoukkary SS, Mostyka M, Dillard A, Berman DR, Ma LX, Chadburn A, et al. Autopsy Findings in 32 Patients with COVID-19: A Single-Institution Experience. Pathobiology. 2020:1-13. 
38. Negrini S, Pappalardo F, Murdaca G, Indiveri F, Puppo F. The antiphospholipid syndrome: from pathophysiology to treatment. Clin Exp Med. 2017;17(3):257-67.

39. Ruiz-Irastorza G, Crowther M, Branch W, Khamashta MA. Antiphospholipid syndrome. Lancet. 2010;376(9751):1498-509.

40. Sokolowska M, Lukasik Z, Agache I, Akdis CA, Akdis D, Akdis M, et al. Immunology of COVID19: mechanisms, clinical outcome, diagnostics and perspectives - a report of the European Academy of Allergy and Clinical Immunology (EAACI). Allergy. 2020.

41. Harzallah I, Debliquis A, Drenou B. Lupus anticoagulant is frequent in patients with Covid-19. J Thromb Haemost. 2020;18(8):2064-5.

42. Khan M, Ibrahim RH, Siddiqi SA, Kerolos Y, Al-Kaylani MM, AlRukn SA, et al. COVID-19 and acute ischemic stroke - A case series from Dubai, UAE. Int J Stroke. 2020;15(6):699-700.

43. Vechi HT, Maia LR, Alves MDM. Late acute pulmonary embolism after mild Coronavirus Disease 2019 (COVID-19): a case series. Rev Inst Med Trop Sao Paulo. 2020;62:e63.

44. Mao L, Jin H, Wang M, Hu Y, Chen S, He Q, et al. Neurologic Manifestations of Hospitalized Patients With Coronavirus Disease 2019 in Wuhan, China. JAMA Neurol. 2020;77(6):683-90.

45. Zhang Y, Liu L, Zhao Q. Author response to Letter to the Editor 'Liver impairment associated with disease progression in COVID-19 patients'. Liver Int. 2020;40(7):1791.

46. Fan S, Xiao M, Han F, Xia P, Bai X, Chen H, et al. Neurological Manifestations in Critically III Patients With COVID-19: A Retrospective Study. Front Neurol. 2020;11:806.

47. Xiong W, Mu J, Guo J, Lu L, Liu D, Luo J, et al. New onset neurologic events in people with COVID-19 in 3 regions in China. Neurology. 2020;95(11):e1479-e87.

48. Barrios-López JM, Rego-García I, Muñoz Martínez C, Romero-Fábrega JC, Rivero Rodríguez M, Ruiz Giménez JA, et al. Ischaemic stroke and SARS-CoV-2 infection: A causal or incidental association? Neurologia. 2020;35(5):295-302.

49. Basi S, Hamdan M, Punekar S. Clinical course of a 66-year-old man with an acute ischaemic stroke in the setting of a COVID-19 infection. BMJ Case Rep. 2020;13(8).

50. Bigliardi G, Ciolli L, Giovannini G, Vandelli L, Dell'Acqua ML, Borzi GM, et al. Middle cerebral artery ischemic stroke and COVID-19: a case report. J Neurovirol. 2020.

51. Bonardel C, Bonnerot M, Ludwig M, Vadot W, Beaune G, Chanzy B, et al. Bilateral posterior cerebral artery territory infarction in a SARS-Cov-2 infected patient: discussion about an unusual case. J Stroke Cerebrovasc Dis. 2020;29(9):105095.

52. D'Anna L, Kwan J, Brown Z, Halse O, Jamil S, Kalladka D, et al. Characteristics and clinical course of Covid-19 patients admitted with acute stroke. J Neurol. 2020:1-5.

53. Díaz-Pérez C, Ramos C, López-Cruz A, Muñoz Olmedo J, Lázaro González J, De Vega-Ríos E, et al. Acutely altered mental status as the main clinical presentation of multiple strokes in critically ill patients with COVID-19. Neurol Sci. 2020;41(10):2681-4.

54. Duroi I, Van Durme F, Bruyns T, Louage S, Heyse A. Fatal Ischaemic Stroke During COVID-19 and Acute Lung Injury. Eur J Case Rep Intern Med. 2020;7(6):001732.

55. Fara MG, Stein LK, Skliut M, Morgello S, Fifi JT, Dhamoon MS. Macrothrombosis and stroke in patients with mild Covid-19 infection. J Thromb Haemost. 2020;18(8):2031-3.

56. Gemcioglu E, Erden A, Davutoglu M, Karabuga B, Kucuksahin O. Acute Ischemic Stroke in a Lupus Anticoagulant-Positive Woman With COVID-19. J Clin Rheumatol. 2020;26(6):236-7.

57. González-Pinto T, Luna-Rodríguez A, Moreno-Estébanez A, Agirre-Beitia G, RodríguezAntigüedad A, Ruiz-Lopez M. Emergency room neurology in times of COVID-19: malignant ischaemic stroke and SARS-CoV-2 infection. Eur J Neurol. 2020.

58. Helms J, Kremer S, Merdji H, Clere-Jehl R, Schenck M, Kummerlen C, et al. Neurologic Features in Severe SARS-CoV-2 Infection. N Engl J Med. 2020;382(23):2268-70.

59. Immovilli P, Terracciano C, Zaino D, Marchesi E, Morelli N, Terlizzi E, et al. Stroke in COVID-19 patients-A case series from Italy. Int J Stroke. 2020;15(6):701-2. 
60. Klok FA, Kruip M, van der Meer NJM, Arbous MS, Gommers D, Kant KM, et al. Incidence of thrombotic complications in critically ill ICU patients with COVID-19. Thromb Res.

2020;191:145-7.

61. Lapergue B, Lyoubi A, Meseguer E, Avram I, Denier C, Venditti L, et al. Large vessel stroke in six patients following SARS-CoV-2 infection: a retrospective case study series of acute thrombotic complications on stable underlying atherosclerotic disease. Eur J Neurol. 2020.

62. Lodigiani C, Iapichino G, Carenzo L, Cecconi M, Ferrazzi P, Sebastian T, et al. Venous and arterial thromboembolic complications in COVID-19 patients admitted to an academic hospital in Milan, Italy. Thromb Res. 2020;191:9-14.

63. Mohamed IZB, Balson L, Madathil S. Massive bilateral stroke in a COVID-19 patient. BMJ Case Rep. 2020;13(8).

64. Morassi M, Bagatto D, Cobelli M, D'Agostini S, Gigli GL, Bnà C, et al. Stroke in patients with SARS-CoV-2 infection: case series. J Neurol. 2020;267(8):2185-92.

65. Roy D, Hollingworth M, Kumaria A. A case of malignant cerebral infarction associated with COVID-19 infection. Br J Neurosurg. 2020:1-4.

66. TunÇ A, ÜnlübaŞ Y, Alemdar M, AkyÜz E. Coexistence of COVID-19 and acute ischemic stroke report of four cases. J Clin Neurosci. 2020;77:227-9.

67. Zayet S, Klopfenstein T, Kovảcs R, Stancescu S, Hagenkötter B. Acute Cerebral Stroke with Multiple Infarctions and COVID-19, France, 2020. Emerg Infect Dis. 2020;26(9):2258-60.

68. Avula A, Nalleballe K, Narula N, Sapozhnikov S, Dandu V, Toom S, et al. COVID-19 presenting as stroke. Brain Behav Immun. 2020;87:115-9.

69. Deliwala S, Abdulhamid S, Abusalih MF, Al-Qasmi MM, Bachuwa G. Encephalopathy as the Sentinel Sign of a Cortical Stroke in a Patient Infected With Coronavirus Disease-19 (COVID19). Cureus. 2020;12(5):e8121.

70. Elshereye A, Erdinc B. Multiple Lacunar Cerebral Infarcts as the Initial Presentation of COVID19. Cureus. 2020;12(8):e9638.

71. Esenwa C, Cheng NT, Lipsitz E, Hsu K, Zampolin R, Gersten A, et al. COVID-19-Associated Carotid Atherothrombosis and Stroke. AJNR Am J Neuroradiol. 2020.

72. Goldberg MF, Goldberg MF, Cerejo R, Tayal AH. Cerebrovascular Disease in COVID-19. AJNR Am J Neuroradiol. 2020;41(7):1170-2.

73. Gunasekaran K, Amoah K, Rajasurya V, Buscher MG. Stroke in a young COVID-19 patient. Qjm. 2020;113(8):573-4.

74. Jillella DV, Janocko NJ, Nahab F, Benameur K, Greene JG, Wright WL, et al. Ischemic stroke in COVID-19: An urgent need for early identification and management. PLoS One. 2020;15(9):e0239443.

75. Kariyanna PT, Chandrakumar HP, Jayarangaiah A, Khan A, Vulkanov V, Ashamalla M, et al. Apical Takotsubo Cardiomyopathy in a COVID-19 Patient Presenting with Stroke: A Case Report and Pathophysiologic Insights. Am J Med Case Rep. 2020;8(10):350-7.

76. Katz JM, Libman RB, Wang JJ, Sanelli P, Filippi CG, Gribko M, et al. Cerebrovascular Complications of COVID-19. Stroke. 2020;51(9):e227-e31.

77. Kihira S, Schefflein J, Mahmoudi K, Rigney B, B ND, Mocco J, et al. Association of Coronavirus Disease (COVID-19) With Large Vessel Occlusion Strokes: A Case-Control Study. AJR Am J Roentgenol. 2020:1-6.

78. Kvernland A, Kumar A, Yaghi S, Raz E, Frontera J, Lewis A, et al. Anticoagulation use and Hemorrhagic Stroke in SARS-CoV-2 Patients Treated at a New York Healthcare System. Neurocrit Care. 2020:1-12.

79. Xia P, Wen Y, Duan Y, Su H, Cao W, Xiao M, et al. Clinicopathological Features and Outcomes of Acute Kidney Injury in Critically III COVID-19 with Prolonged Disease Course: A Retrospective Cohort. J Am Soc Nephrol. 2020;31(9):2205-21.

80. Mahboob S, Boppana SH, Rose NB, Beutler BD, Tabaac BJ. Large vessel stroke and COVID-19: Case report and literature review. eNeurologicalSci. 2020;20:100250. 
81. Majidi S, Fifi JT, Ladner TR, Lara-Reyna J, Yaeger KA, Yim B, et al. Emergent Large Vessel Occlusion Stroke During New York City's COVID-19 Outbreak: Clinical Characteristics and Paraclinical Findings. Stroke. 2020;51(9):2656-63.

82. Oxley TJ, Mocco J, Majidi S, Kellner CP, Shoirah H, Singh IP, et al. Large-Vessel Stroke as a Presenting Feature of Covid-19 in the Young. N Engl J Med. 2020;382(20):e60.

83. Patel HN, Syed A, Lobel JS, Galler R, Georges J, Carmody M, et al. Cerebellar infarction requiring surgical decompression in patient with COVID 19 pathological analysis and brief review. Interdiscip Neurosurg. 2020;22:100850.

84. Reddy ST, Garg T, Shah C, Nascimento FA, Imran R, Kan P, et al. Cerebrovascular Disease in Patients with COVID-19: A Review of the Literature and Case Series. Case Rep Neurol. 2020;12(2):199-209.

85. Rothstein A, Oldridge O, Schwennesen H, Do D, Cucchiara BL. Acute Cerebrovascular Events in Hospitalized COVID-19 Patients. Stroke. 2020;51(9):e219-e22.

86. Valderrama EV, Humbert K, Lord A, Frontera J, Yaghi S. Severe Acute Respiratory Syndrome Coronavirus 2 Infection and Ischemic Stroke. Stroke. 2020;51(7):e124-e7.

87. Yaghi S, Ishida K, Torres J, Mac Grory B, Raz E, Humbert K, et al. SARS-CoV-2 and Stroke in a New York Healthcare System. Stroke. 2020;51(7):2002-11.

88. Zahid MJ, Baig A, Galvez-Jimenez N, Martinez N. Hemorrhagic stroke in setting of severe COVID-19 infection requiring Extracorporeal Membrane Oxygenation (ECMO). J Stroke Cerebrovasc Dis. 2020;29(9):105016.

89. Garg A, Marji A, Goyal S, Ismail R. A Case of COVID-19 With Memory Impairment and Delayed Presentation as Stroke. Cureus. 2020;12(8):e10025. 


\section{Figure Legends}

\section{Figure 1: The percent prevalence of Lupus anticoagulant (LA) in COVID-19 patient}

populations: $\mathrm{N}=$ number of patients, Ref= Reference.

Figure 2. The percent prevalence of aPL in stroke patients with COVID-19 as compared to the general population. At least one aPL assay was positive in 38 of 65 (58.4\%) patients with COVID-19 and stroke. The average age in these patient series was $68.0,66.6,65.2,65.0,64.0,61.9$, and 47.6 years. The overall frequency of aPL in stroke patients in general population was 13.5\% (643/4765) in a recent review of 31 studies (22). The age of patients in these 31 studies ranged from 2 years to 88 years. The differences in age distribution, comorbidities, and overall health status are major limitation of our analysis. ${ }^{*} \mathrm{p}<0.0001$, Fisher's exact test. 
Table 1. Prevalence of positive antiphospholipid assays in patients with COVID-19

\begin{tabular}{|c|c|c|c|c|c|}
\hline $\begin{array}{l}\text { Location } \\
\text { [Ref.] }\end{array}$ & Patient cohort & LA & $\mathrm{aCL}$ & aß2GP1 & Comment \\
\hline UK (9) & $\begin{array}{l}44(20 \%) \text { of } 216 \text { patients with SARS-COV-2 } \\
\text { PCR+ vs. } 43(8 \%) \text { of } 540 \text { control specimens } \\
\text { sent for LA testing had a prolonged aPTT }\end{array}$ & $\begin{array}{l}\text { Among those with a prolonged } \\
\text { aPTT, LA+ in } 31 / 34(91 \%) \text { patients } \\
\text { with SARS-COV-2 vs. } 11 / 43(26 \%) \\
\text { controls }(p<0.001)\end{array}$ & $\mathrm{N} / \mathrm{A}$ & $\mathrm{N} / \mathrm{A}$ & $\begin{array}{l}\text { Heparin detected in most specimens, but the dRVVT } \\
\text { assay contains heparinase, which neutralizes any } \\
\text { heparin effect that might lead to false positive LA. }\end{array}$ \\
\hline France (18) & 25 critically ill COVID-19 patients & $92 \%$ (dRVVT) & $52 \%$ & $12 \%$ & Single aPL $32 \%$, double $52 \%$, triple $12 \%$ \\
\hline $\begin{array}{l}\text { New York, } \\
\text { USA (10) }\end{array}$ & $\begin{array}{l}\text { All LA test orders at a tertiary hospital: } 68 \\
\text { SARS-CoV-2+ and } 119 \text { negative }\end{array}$ & $\begin{array}{l}\text { SARS-CoV-2+ patients: } 44 \% \\
\text { SARS-CoV-2-: } 22 \% \text { (p 0.002) }\end{array}$ & $\begin{array}{l}1 \mathrm{lgM} \text { aCL+ among LA+ } \\
\text { patients }\end{array}$ & $\begin{array}{l}1 \text { lgM aß2GP1+ among LA+ } \\
\text { patients }\end{array}$ & $\begin{array}{l}\text { IgA antibodies not tested. } \\
\text { Disease duration not known. }\end{array}$ \\
\hline Italy (11) & $\begin{array}{l}122 \text { patients with COVID-19, } \\
157 \text { primary APS, and } \\
91 \text { oARD }\end{array}$ & $\begin{array}{l}\text { COVID-19: } \\
\text { Primary APS: } \\
\text { oARD: }\end{array}$ & $\begin{array}{l}\lg \mathbf{1 3} \%, \lg M 3 \%, \lg A 2 \% \\
\lg 68 \%, \lg M 38 \% \\
\lg \mathrm{g} 13 \%, \lg M 14 \%\end{array}$ & $\begin{array}{l}\lg 6 \%, \lg M 7 \%, \lg A 3 \% \\
\lg 37 \%, \lg M 43 \% \\
\lg 21 \%, \lg M 11 \%\end{array}$ & $\begin{array}{l}\text { Frequency of aPL in COVID-19 lower vs. primary } \\
\text { APS, but } L A \text {, IgG } a C L \text {, and IgM a } 32 G P 1 \text { frequencies } \\
\text { comparable to oARD. }\end{array}$ \\
\hline France (41) & 56 patients with COVID-19 & $56 \%$ (dRVVT, LA-sensitive aPTT) & $10 \%(\operatorname{lgM} / \operatorname{lgG}$ aCL or & $\mathrm{a} \beta 2 \mathrm{GP} 1)$ & IgA antibodies not tested. \\
\hline Spain (19) & 24 patients with VTE admitted to ICU & NA & $8.3 \%$ with weakly $+\lg M$ & $8.3 \%$ with weakly + lgM & Tested within 14 days of admission \\
\hline Italy (15) & 122 severe or critical patients & NA (Prolonged aPTT in 58\%) & $\lg \mathrm{G} 6 \%, \lg M 7 \%$ & $\lg \mathbf{G} 16 \%, \lg M 9 \%, \lg A 7 \%$ & aPS/PT IgG 3\%, lgM 10\% \\
\hline Belgium (20) & 31 consecutive patients admitted to ICU & $67 \%$ & $\lg \mathbf{1 9} \%, \lg M 3 \%, \lg A 10 \%$ & $\lg \mathbf{1 0} \%, \lg M 3 \%, \lg A 10 \%$ & $\begin{array}{l}74 \% \text { patients had at least } 1 \text { aPL. } \dagger \\
\text { aPS/PT: } 3 \text { IgG, } 4 \text { lgM. (All } 7 \text { LA+) }\end{array}$ \\
\hline China (12) & $\begin{array}{l}\text { Wuhan cohort: } 66 \text { critically ill, older (mean } \\
\text { age } \geq 65 \text { years) patients, } \\
\text { Beijing cohort: } 13 \text { non-critically ill with a } \\
\text { mean age of } 35 \text { years }\end{array}$ & $\begin{array}{l}\text { Wuhan: } 3 \% \text { (dRVVT). } \\
\text { 0/13 of Beijing cohort vs. } 47 \% \\
\text { (31/66) Wuhan patients had an } \\
\text { aPL. }\end{array}$ & $\begin{array}{l}\operatorname{lgG} 6 \%, \operatorname{lgM} 3 \%, \lg A 26 \% \\
\text { (Wuhan cohort, } n=66 \text { ). }\end{array}$ & $\begin{array}{l}\lg \mathrm{G} 18 \%, \lg \mathrm{M} 2 \%, \lg \mathrm{A} 29 \% \\
\text { (Wuhan cohort). }\end{array}$ & $\begin{array}{l}\text { aPL emerged } \sim 35-39 \text { days post-disease onset. } 10 \\
\text { aPL- patients at early time point became aPL+ at a } \\
\text { later time point. Any aPL } 47 \% \text {, double }+44 \% \text {, triple+ } \\
3 \%\end{array}$ \\
\hline China (13) & $\begin{array}{l}19 \text { critically ill patients admitted to ICU in } \\
\text { Wuhan }\end{array}$ & $\begin{array}{l}5 \%(\mathrm{dRVVT}) \text {. } \\
53 \% \text { patients had at least } 1 \mathrm{aPL} \text {. }\end{array}$ & $\lg \mathrm{g} 11 \%, \lg M 5 \%, \lg A 32 \%$ & $\lg \mathrm{3} 3 \%, \lg M 0, \lg A 37 \%$ & $\begin{array}{l}\text { Specimens obtained } 29-32 \text { days after symptom } \\
\text { onset. } \ddagger\end{array}$ \\
\hline France (14) & $\begin{array}{l}74 \text { consecutive mechanically ventilated } \\
\text { patients on anticoagulation }\end{array}$ & $\begin{array}{l}85 \% \text { (dRVVT). } \\
88 \% \text { patients had at least } 1 \mathrm{aPL} .\end{array}$ & $\begin{array}{l}12 \% \text { (lgG/lgM aCL and/or } \\
\operatorname{lgG} \text { aß2GP1). }\end{array}$ & $\begin{array}{l}1 \text { triple+, } 2 \text { LA- } \\
\text { aCL/aß2GP1+ }\end{array}$ & $\lg \mathrm{A}$ antibodies and $\operatorname{lgM}$ aß2GP1 not tested. \# \\
\hline Mexico (17) & $\begin{array}{l}21 \text { patients with severe or critical COVID-19 } \\
\text { (18 anticoagulated) }\end{array}$ & NA & $\operatorname{lgG} 10 \%, \lg M 14 \%$ & $\lg \mathrm{G} 5 \%, \lg \mathrm{M} 0$ & $\begin{array}{l}\text { Anti-annexin V: } \lg \text { G } 5 \%, \operatorname{lgM} 19 \% \\
\text { aPS: } \lg \text { Ig } 10 \%, \lg M 14 \%\end{array}$ \\
\hline $\begin{array}{l}\text { Michigan, } \\
\text { USA (16) }\end{array}$ & 172 patients hospitalized with COVID-19. & $\begin{array}{l}\text { NA. } \\
\text { Any aPL + in } 52 \% \text {. }\end{array}$ & $\lg \mathrm{g} 5 \%, \lg M 23 \%, \lg A 4 \%$ & $\lg G 3 \%, \lg M 5 \%, \lg A 4 \%$ & $\begin{array}{l}\text { aPS/PT: IgG in } 24 \%, \operatorname{lgM} 18 \% \text {. } \\
>1 \text { type of aPL in } 24 \% \text {, and }>2 \text { in } 8 \% . \oplus\end{array}$ \\
\hline
\end{tabular}

* LA tested by dRVVT and silica clotting time. $\nmid 2$ patients triple+, $3 \mathrm{LA}+\operatorname{lgG} \mathrm{aCL}+, 2 \mathrm{LA}-\lg \mathrm{aCL}+$ and/or $\lg \mathrm{g}$ a $2 \mathrm{GP} 1+.9 / 10 \mathrm{LA}+$ patients tested negative on a 2nd occasion. $\ddagger$ Seven of 10 patients had multiple isotypes. 1 triple + . Some patients had very high levels of IgA antibodies. \# aCL/aß2GP1+ patients tended to have been 
tested longer after COVID-19 symptoms started than the negative patients $(p=.06)$. $\oplus$ Moderate-to-high level aPL antibodies present in $30 \%$ patients. Most specimens collected at $0-15$ hospital day.

+, positive; -, negative; aß2GP1, anti-ß2 glycoprotein 1 antibody; aCL, anti-cardiolipin antibody; aPL, antiphospholipid antibody; APS, antiphospholipid syndrome; aPS, anti-phosphatidylserine; aPT, anti-prothrombin; aPTT, activated partial-thromboplastin time; dRVVT, diluted Russell viper venom test; ICU, intensive care unit; LA, lupus anticoagulant; NA, not assessed / not available; OARD, other autoimmune rheumatic diseases. 
Table 2. Reports of antiphospholipid assays in patients with COVID-19 and thrombosis

\begin{tabular}{|c|c|c|c|}
\hline $\begin{array}{l}\text { Location } \\
\text { [Ref.] }\end{array}$ & Patient cohort & Thrombotic manifestations & Relationship with aPL positivity \\
\hline $\begin{array}{l}\text { Wuhan, } \\
\text { China (4) }\end{array}$ & 3 critically ill patients with COVID-19 & $\begin{array}{l}\text { Multiple cerebral infarctions, acute limb ischemia, acro- } \\
\text { ischemia }\end{array}$ & - $\quad 3 / 3$ + for multiple aPL. All had detectable $\operatorname{lgA}$ aCL and aß2GP1 \\
\hline $\begin{array}{l}\text { Wuhan, } \\
\text { China (12) }\end{array}$ & 66 critically ill patients with COVID-19 & $\begin{array}{l}\text { Arterial in } 6(9 \%) \text { patients (cerebral infarction } 5 \text {, myocardial } \\
\text { infarction } 1) \text {, venous in } 19(29 \%) \text { (large veins 2, distal } \\
\text { veins } 17)\end{array}$ & $\begin{array}{l}\text { - Arterial and large vein thrombosis seen only in patients with multiple aPL at } \\
\text { medium/high levels. } \\
\text { - Cerebral infarction in aPL- vs. multiple aPL+ patients ( } 0 \text { vs. } 33 \%, p \text { 0.02). }\end{array}$ \\
\hline $\begin{array}{l}\text { Wuhan, } \\
\text { China (13) }\end{array}$ & $\begin{array}{l}19 \text { ICU patients with COVID-19; all on } \\
\text { anticoagulation }\end{array}$ & $\begin{array}{l}12 \text { thrombotic events in } 9 \text { patients }(47 \%): 4 \text { cerebral } \\
\text { infarction, } 7 \text { acro-ischemia, and } 1 \text { internal jugular vein } \\
\text { thrombosis. }\end{array}$ & $\begin{array}{l}\text { - } 9 / 10 \mathrm{aPL}+\text { vs. } 0 / 9 \mathrm{aPL}-\text { patients had a thrombotic event. } \\
\text { - All } 4 \text { patients with cerebral infarction had aPL of multiple isotypes incl. IgA aCL } \\
\text { and aß2GP1. }\end{array}$ \\
\hline Italy (11) & $\begin{array}{l}53 \text { hospitalized patients and } 69 \text { in home } \\
\text { quarantine; } 89 \% \text { on anticoagulation }\end{array}$ & $\begin{array}{l}\text { 18/46 (39\%) hospitalized patients had thrombosis, incl. } 17 \\
\text { VTE and } 1 \text { stroke. No thrombosis in quarantined patients. }\end{array}$ & $\begin{array}{l}\text { - } 50 \% \text { of } 53 \text { hospitalized patients had at least } 1 \mathrm{aPL} \text { (LA } 17 \% \text {, lgG/lgM/lgA } \\
\text { aCL/aß2GP1 ranged } 4 \%-19 \%) \text {. } \\
\text { - } 10 / 41(24 \%) \text { aPL+ vs. } 8 / 65(12 \%) \text { aPL- patients had thrombosis (p 0.09). }\end{array}$ \\
\hline Italy (15) & $\begin{array}{l}122 \text { severe or critical patients; } 98 \% \\
\text { anticoagulated }\end{array}$ & 16 thrombotic events (13\%), 8 each of venous and arterial. & $\begin{array}{l}\text { - No significant association between thrombosis and } \mathrm{aPL}(\operatorname{lgG} / \operatorname{lgM} \mathrm{aCL} \text { and } \\
\operatorname{lgG} / \operatorname{lgM} / \operatorname{lgA} \text { aß2GP1 ranged } 6 \%-16 \%) \text {. }\end{array}$ \\
\hline France (14) & $\begin{array}{l}74 \text { mechanically ventilated patients on } \\
\text { anticoagulation }\end{array}$ & $\begin{array}{l}28 \text { patients ( } 38 \% \text { ) had a thrombosis, incl. } 26 \text { DVT, } 4 \text { PE, } 1 \\
\text { stroke and } 1 \text { extensive venous catheter thrombosis. }\end{array}$ & $\begin{array}{l}\text { - } \operatorname{lgG} / \operatorname{lgM} \text { aCL and/or } \operatorname{lgG} \text { aß2GP1 + in } 18 \% \text { patients with thrombosis and } 9 \% \\
\text { without thrombosis ( } \mathrm{p} \mathrm{NS} \text { ). } \\
\text { - } \mathrm{LA}+\text { in } 82 \% \text { of } 28 \text { patients with thrombosis vs. } 87 \% \text { of } 46 \text { without it. }\end{array}$ \\
\hline France (18) & 25 critically ill patients & PE in 6 patients & $\begin{array}{l}\text { - } \quad \mathrm{LA}+\text { in } 92 \% \text { patients, aCL in } 52 \%, \mathrm{~A} \beta 2 \mathrm{GP} 1 \text { in } 12 \% \\
\text { - } \quad \text { All } 6 \text { patients who had PE were aPL+, of whom } 4 \text { were double + }\end{array}$ \\
\hline Spain (19) & $\begin{array}{l}24 \text { of } 785 \text { COVID-19 patients who had } \\
\text { VTE (3\%) }\end{array}$ & $\begin{array}{l}\text { DVT alone } 9(38 \%), \text { PE alone } 11(46 \%), \text { DVT+PE } 4(17 \%) \text {, } \\
\text { arterial thrombosis } 0\end{array}$ & - 2 patients (8.3\%) with weakly positive lgM aCL and aß2GP1. None with lgG aPL \\
\hline $\begin{array}{l}\text { Belgium } \\
(20)\end{array}$ & 31 ICU patients with COVID-19 & $\begin{array}{l}12 \text { events - CVC thrombosis } 4 \text {, DVT } 2 \text {, ECMO clotting } 3 \text {, } \\
\text { dialysis circuit } 2 \text {, stroke } 1\end{array}$ & $\begin{array}{l}\text { - } 7 / 9(78 \%) \text { patients with thrombosis vs. } 16 / 22(73 \%) \text { without thrombosis had at } \\
\text { least } 1 \mathrm{aPL} \text {. }\end{array}$ \\
\hline UK (21) & 4 COVID-19 with stroke & Stroke (4/4), PE (1/4) & - $\quad L A+$ in $4 / 4$ \\
\hline Mexico (17) & $\begin{array}{l}21 \text { severe or critical patients; } 18 \\
\text { anticoagulated }\end{array}$ & $P E$ in $2 / 21$ patients & $\begin{array}{l}\text { - } 12 / 21+\text { for at least } 1 \mathrm{aPL} . \\
\text { - } \quad \text { VTE in } 2 / 12 \mathrm{aPL}+\mathrm{vs} .0 / 9 \mathrm{aPL}-\end{array}$ \\
\hline $\begin{array}{l}\text { Michigan, } \\
\text { USA (16) }\end{array}$ & $\begin{array}{l}172 \text { hospitalized patients; most on } \\
\text { anticoagulation. }\end{array}$ & $\begin{array}{l}11 \text { patients with thrombosis: arterial } 2(1 \%) \text {, venous } 8 \\
(5 \%) \text {, both } 1(0.6 \%) \text {. }\end{array}$ & $\begin{array}{l}\text { - Any aPL + in } 89(52 \%) \text { patients. } \\
\text { - } \quad 6 / 11(55 \%) \text { patients with thrombosis were } \mathrm{aPL}+.\end{array}$ \\
\hline $\begin{array}{l}\text { New York, } \\
\text { USA (10) }\end{array}$ & $\begin{array}{l}68 \text { patients who had LA test orders and } \\
\text { PCR+ for SARS-COV-2 }\end{array}$ & $\begin{array}{l}8 \text { arterial events (incl. } 2 \text { stroke) and } 11 \text { VTE (incl. } 3 \text { PE) in } \\
\text { LA+ patients vs. all VTE events in LA- patients }\end{array}$ & $\begin{array}{l}\text { - Thrombosis in } 63 \% \text { of } 30 \mathrm{LA}+\mathrm{vs.} 34 \% \text { of } 38 \mathrm{LA}-\text { patients }(\mathrm{p}<0.03) \\
\text { - } \quad \text { LA independently associated with thrombosis: OR } 4.4(95 \% \mathrm{Cl}, 1.5-14.6), \mathrm{p} 0.01 \text {. }\end{array}$ \\
\hline UAE (42) & 22 patients with ischemic stroke & 22 acute ischemic stroke & - Of 6 patients tested, 1 was +, Specific antibody not mentioned. \\
\hline Brazil (43) & 5 patients with mild infection & All 5 with acute PE & - $4 / 5$ positive for $L A C, 2 / 5$ aCL IgM, 1/5 Aß2 IgM \\
\hline
\end{tabular}

Additional reports of one to two COVID-19 patients with thrombosis who were tested for aPL are summarized in Appendix Table 2. Comorbid conditions of these patients are summarized in Appendix Table 3. 
+, positive; -, negative; aß2GP1, anti-ß2 glycoprotein 1 antibody; aCL, anti-cardiolipin antibody; aPL, antiphospholipid antibody; CVC, central venous catheter; CVD, cardiovascular disease; DM, diabetes mellitus; dRVVT, diluted Russell viper venom test; DVT, deep vein thrombosis; HTN, hypertension; incl., including; ICU, intensive care unit; LA, lupus anticoagulant; OR, odds ratio; PE, pulmonary embolism; VTE, venous thromboembolism 
Table 3. Cerebral infarction/stroke in patients with COVID-19

\begin{tabular}{|c|c|c|c|c|}
\hline Location (Ref) & $\begin{array}{l}\text { Total number of ischemic } \\
\text { stroke patients [N] }\end{array}$ & $\begin{array}{l}\text { Number of patients } \\
\text { tested for aPL }\left[N^{*}\right]\end{array}$ & $\begin{array}{l}\text { Number of aPL positive } \\
\text { stroke patients }(\%)\left[\mathrm{N}^{\star \star}\right]\end{array}$ & $\begin{array}{l}\text { Number of these patients } \\
\text { with } \geq 2 \text { aPL }(\%)\left[N^{\star *}\right]\end{array}$ \\
\hline China $(4,12,13,44-47)$ & $44[7]$ & $18[4 / 7]$ & $17(94.4)[4 / 4]$ & $12 / 12(100)[3 / 4]$ \\
\hline Europe $(21,48-67)$ & $64[21]$ & $20[9 / 21]$ & $11(55.0)[5 / 9]$ & $1 / 11(9.1)[1 / 9]$ \\
\hline USA $(23,24,55,68-89)$ & $330[23]$ & 27 [7/23] & $10(37.0)[4 / 7]$ & $\mathrm{N} / \mathrm{A}$ \\
\hline Total & $438[51]$ & $65[20 / 51]$ & $38[13 / 20]$ & $13 / 23[4 / 13]$ \\
\hline
\end{tabular}

$\mathrm{N}$, Number of studies; *, number of studies that tested for aPL/number of studies that reported stroke; ${ }^{*}$, number of studies showing + aPL/number of studies that tested for aPL; N/A= Information not available. 
Xiao, et al., Wuhan $-3 \%, \mathrm{~N}=66$

Reyes Gil,et al., New York -

$44 \%, N=68$

Gatto, et al., Italy

$\frac{\vec{\partial}}{\partial}$

Devrees, et al., Belgium Harzallah, et al., France -

$22 \%, N=122$

Siguret, et al., France -

Pineton de Chambrun, et al., France

$67 \%, N=31$

Bowles, et al., UK-

$\begin{array}{llllll}0 & 20 & 40 & 60 & 80 & 100\end{array}$

Percent prevalence of $L A$ 


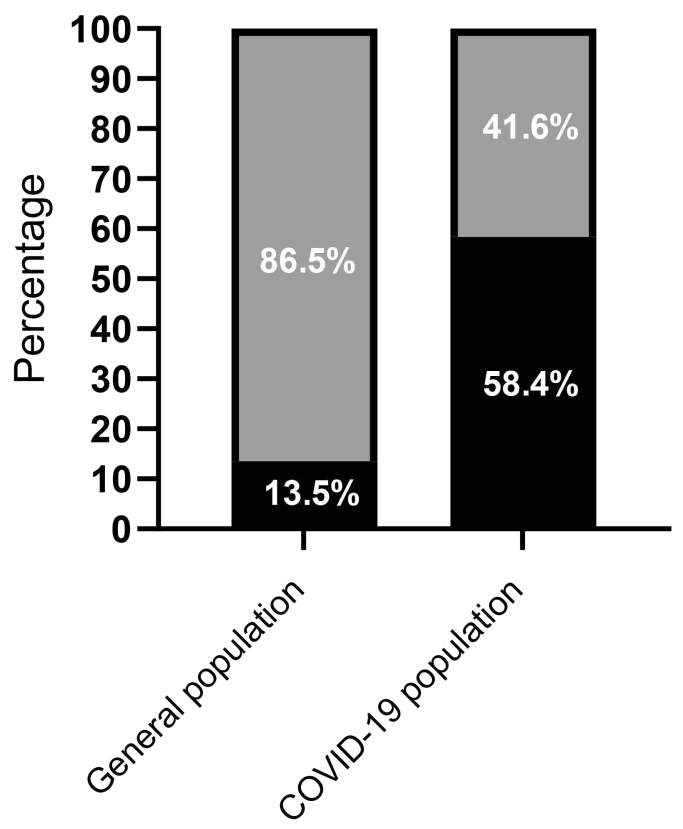

ㅁ aPL negative - aPL positive 